\title{
PENYUSUNAN RENCANA STRATEGIS DALAM PENGEMBANGAN BUDAYA MUTU PENDIDIKAN DI SEKOLAH TINGGI AGAMA ISLAM SYEKH H. ABDUL HALIM HASAN AL ISHLAHIYAH BINJAI
}

\author{
Syafaruddin, Mesiono, Muhammedi \\ UIN North Sumatra, Medan North Sumatra \\ UIN North Sumatra, Medan North Sumatra \\ Universitas Al-Azhar Medan \\ * Correspondence: muham_medi@yahoo.com
}

\begin{abstract}
Formulating a strategic plan in developing a culture of quality education at the Islamic High School of Sheikh H. Abdul Halim Hasan Al Ishlahiyah Binjai by: first, formulating the vision, mission, and goals; second, forming a Strategic Plan Drafting Team; third, the formulation process; and fourth, the ratification of the strategic plan. The Strategic Plan Drafting Team consists of the Head of STAI, Deputy Chair, Head of the Quality Assurance Unit, Ka. Study programs, and lecturers. Each party involved in formulating programs and strategies in accordance with their respective fields and for educational quality goals manages facilities, from procurement, maintenance and repair, to development that can create a clean, neat, and beautiful campus environment so as to create pleasant conditions. both for lecturers and students to be on campus. Preparation of strategic programs, namely the development of study programs, facilities and infrastructure, governance and management, development of human resources (HR), funds and funding, quality assurance, research, community service, and cooperation by developing a quality culture, namely: open and continuous communication, mutually supportive internal partnerships, teamwork, discipline, and responsibility. The next step is to socialize it to stakeholders, the academic community, and public and private agencies so that the strategic plan that has been prepared will be successful.
\end{abstract}

Keywords: Preparation, Strategic Planning, Education Quality Culture, STAI

\begin{abstract}
ABSTRAK
Penyusunan rencana strategis dalam pengembangan budaya mutu pendidikan di Sekolah Tinggi Agama Islam Syekh H. Abdul Halim Hasan Al Ishlahiyah Binjai dengan: pertama, merumuskan visi, misi, dan tujuan; kedua, membentuk Tim Penyusun Rencana Strategis; ketiga, proses perumusan; dan keempat, pengesahan rencanaan strategis tersebut. Tim Penyusun Rencana Strategis terdiri dari Ketua STAI, Wakil Ketua, Kepala Uinit Penjamin Mutu, Ka. Prodi, dan dosen. Setiap pihak yang terlibat dalam menyusun program dan strategi sesuai dengan bidangnya masing- masing dan untuk sasaran mutu pendidikan mengelola fasilitas, mulai dari pengadaan, pemeliharaan dan perbaikan, hingga pengembangan yang dapat menciptakan lingkungan kampus yang bersih, rapi, ndah sehingga dapat menciptakan kondisi yang menyenangkan baik bagi dosen maupun mahasiswa untuk berada di kampus. Penyusunan program-program strategis, yaitu pengembangan program studi, sarana dan prasarana,tata kelola dan manajemen, pengembangan sumber daya manusia (SDM), dana dan pendanaan, penjaminan mutu, penelitian, pengabdian pada masyarakat, dan kerjasama dengan mengembangkan budaya mutu, yaitu: komuinikasi yang terbuka dan kontiiniu, kemitraan nternal yang saling mendukung, kerjasama tim, kedisiplinan, dan tanggung jawab. Langkah berikutnya adalah mensosialisasikannya kepada stakeholder, civitas akademika, dan nstansi negeridan swasta agar kut mensukseskan rencana strategis yang telah disusun.
\end{abstract}




\section{A. PENDAHULUAN}

Istilah rencana strategis berasal dari bidang militer yang kemudian dikembangkan dalam berbagai liini kehidupan sebagai rencana yg cermat mengenai kegiatan untuk mencapai sasaran khusus seperti di bidang manajemen perusahaan yang kemudian diterapkan dalam duinia pendidikan (Kerzner, 2001: 13). Rencana strategis berfungsi untuk menuntun segenap penyelenggara uinit dalam suatu orgainisasi dalam melaksanakan program dan kegiatan pembangunan sesuai dengan tugas dan fungsi yang diemban, terutama pencapaian visi, misi, tujuan, sasaran dan strategi yang akan dicapai dalam periode lima tahun ke depan. Rencana strategis merupakan tulang punggung manajemen strategis (Burhan, 1994: 42).

\section{Perencanaan strategis} merupakan bagian dari manajemen strategis. Manajemen strategis adalah seini dan lmu untuk pembuatan (formulating), penerapan (implementing), dan evaluasi (evaluating) keputusan-keputusan starategis antar fungsi yang memungkinkan sebuah orgainisasi mencapai tujuan di masa datang. Dengan begitu, perencanaan strategis lebih terfokus pada bagaimana manajemen puncak menentukan visi, misi, falsafah, dan strategi untuk mencapai tujuan jangka panjang (Syafaruddin, 2017: 146).

Robbins dan Coulter mendefeinisikan perencanaan adalah sebagai sebuah proses yang dimulai dari penetapan tujuan orgainisasi, menentukan strategi untuk pencapaian tujuan orgainisasi tersebut secara menyeluruh, serta merumuskan system perencanaan yang menyeluruh untuk mengintegrasikan dan mengoordinasikan seluruh pekerjaan orgainisasi hingga tercapainya tujuan orgainisasi (Robbins, 2001: 32).

Sedangkan strategis adalah rencana komprehensif untuk mencapai tujuan orgainisasi. Tidak hanya sekedar mencapai akan tetapi dima ksudkan untuk mempertahankan keberlangsungan orgainisasi (Sule, Erinie, Saefullah, Kuriniawan, 2005: 23). Rencana strategis merupakan 
pengejewantahan misi, visi, tujuan, program, kegiatan-kegiatan dan prestasi-prestasi yang di lahirkan sebuah orgainisasi.

Rencana strategis merupakan upaya untuk melaksanakan tiga langkah penting yaitu: Pertama, mengidentifikasi kecenderungan, ancaman, dan peluang, dimana hasilnya dapat mengubah kecenderungan historis. Kedua, menyempurnakan performance orgainisasi yang didorong oleh kondisi kompetitif. Ketiga, membandingkan uinit kerja dalam orgainisasi untuk menyusun prioritas pengembangan dengan mengalokasikan sumber daya (Salusu, 2004: 26). Rencana strategis adalah nstrumen yang menjembataini kesenjangan antara rencana tahunan orgainisasi dan rencana jangka panjang tradisional (Donnelly, 2004: 19).

Brian Fidler menyatakan bahwa:

The first and major decision $s$ whether to engage $n$ formal strategic planining. This s not a light decision to take. When the process $s$ announced there will be high expectations of what $s$ to be accomplished. There can be expected to be some disillusionment $f$ the process does not come to a successful conclusion (Fidler, 2002: 96).

Untuk mencapai sebuah strategi yang telah ditetapkan oleh orgainisasi dalam rangka mempunyai keunggulan kompetitif, maka para pimpinan perusahaan, manajer operasi, haruslah bekerja dalam sebuah sistem yang ada pada proses rencana strategis/strategic planining (Hitt, 2011: 23). Kemampuan manufaktur, harus dipergunakan secara tepat, sehingga dapat menjadi sebuah senjata yang unggul dalam sebuah perencanaan stategis.

Ada tiga alasan yang menunjukkan pentingnya rencana strategis:

a. Rencanaan strategis memberikan kerangka dasar bagi perencanaanperencanaan lainnya.

b. Pemahaman terhadap rencanaan strategis akan mempermudah pemahaman bentuk perencanaan lainnya. Rencana strategis merupakan 
titik permulaan bagi peinilaian kegiatan manajer dan orgainisasi.

c. Rencana strategis adalah proses yang dilakukan suatu orgainisasi untuk menentukan strategi atau arahan, serta mengambil keputusan untuk mengalokasikan sumber dayanya (termasuk modal dan sumber daya manusia) untuk mencapai strategi ini. Berbagai tekinik analisis bisinis dapat digunakan dalam proses ini, termasuk analisis SWOT (Strengths, Weaknesses, Opportuinities, Threats), PEST (Political, Economic, Social,

Technological), atau STEER (Socio-cultural,

Technological, Economic, Ecological, Regulatory) (Coutney, 2002: 45).

Dari uraian di atas, dapat disimpulkan bahwa yang dimaksud dengan rencana strategis lembaga pendidikan adalah suatu rencana jangka menengah yang bersifat menyeluruh, memberikan rumusan ke mana lembaga pendidikan akan diarahkan, dan bagaimana sumber daya dialokasikan untuk mencapai tujuan selama jangka waktu tertentu dalam berbagai kemungkinan keadaan lingkungan. Rencana strategis juga merupakan suatu proses pemilihan tujuan-tujuan orgainisasi, penentuan strategi, kebijaksanaan, program-program strategi yang diperlukan untuk tujuan-tujuan tersebut.

Penyusunan rencana strategis senantiasa menjunjung tinggi kebenaran dan kejujuran. Segala program rencana strategis baik tu program yang berjangka panjang maupun program yang berjangka pendek harus direncanakan dengan cermat dan hati-hati sedemikian rupa sehingga akan diperoleh hasil-hasil yang nyata (Anggoro, 2000: 75).

Sebelum membentuk rencana strategis, harus terlebih dahulu memahami tujuan yang ngin dicapai oleh orgainisasinya (Ruslan, 2000: 139-140). Perencanaan merupakan tindakan menetapkan terlebih dahulu apa yang akan dikerjakan, bagaimana mengerjakannya, apa yang harus 
dikerjakan, dan siapa yang mengerjakannya. Perencanaan sering juga disebut jembatan yang menghubungkan kesenjangan atau jurang antara keadaan masa kiini dan keadaan yang diharapkan terjadi pada masa yang akan datang. Meskipun keadaan masa depan yang tepat tu sukar diperkirakan karena banyak faktor di luar penguasaan manusia yang berpengaruh terhadap rencana, tetapi tanpa perencanaan humas kita akan menyerahkan keadaan pada masa yang akan dating tu pada kebetulan-kebetulan. tulah sebabnya diadakannya perencanaan hubungan masyarakat sebagai suatu proses ntelektual yang menentukan secara sadar tindakan yang akan ditempuh.

Manfaat rencana strategis bagi sebuah lembaga pendidikan adalah:

a. Rencana Strategis dapat memperkuat "critical mass". Critical mass merupakan kelompok tenaga nti suatu orgainisasi yang memiliki motivasi, "aptidute" dan (profound knowledge) untuk meiningkatkan produktivitas.

b. Rencana strategis dapat membantu untuk mengoptimisasikan "performance" orgainisasi.

c. Rencana strategis dapat membantu pimpinan untuk selalu memusatkan perhatian dan menganut kerangka bagi perbaikan secara kontinu.

d. Rencana strategis memberikan pedoman bagi pengambilan keputusan.

e. Rencana strategis selalu memberi kemudahan dalam mengukur kemajuan lembaga pendidikan (Hardjosoedarmo, 2004: 76-78).

Pada dasarnya manfaat dari program rencana strategis adalah cara menciptakan budaya mutu pendidikan Islam sehingga memuaskan keinginan masyarakatnya atau stakeholder. Hasil yang diharapkan adalah terciptanya citra positif, kemauan baik, pengertian, toleransi antara kedua belah pihak masyarakatnya atau stakeholder. Hasil yang 
diharapkan adalah terciptanya citra positif, kemauan baik, pengertian, toleransi antara kedua belah pihak.

Penyusunan rencana strategis dilakukan dengan: 1) Menetapkan jeinis usaha orgainisasi. 2) Menterjemahkan visi dan misi ke dalam suatu tujuan strategis yang terukur. 3) Menyusun strategi yang tepat untuk mencapai tujuan dan target. 4) Melakukan berbagai keputusan taktis dengan efektif dan efisien atas strategi terpilih. 5) Melakukan pembagian tugas, penyesuaian terhadap arah, tujuan, strategi dan pelaksanaannya sesuai dengan situasi terbaru (Morell, 1960: 22).

Mutu pendidikan sangat dipengaruhi oleh sejauh mana lembaga mampu mengelola seluruh potensi secara optimal mulai dari tenaga kependidikan, peserta didik, proses pembelajaran, sarana pendidikan, keuangan dan termasuk hubungannya dengan masyarakat. Pada kesempatan ini, lembaga pendidikan Islam harus mampu merubah paradigma baru pendidikan yang berorientasi pada mutu semua aktifitas yang berinteraksi di dalamnya, seluruhnya mengarah pencapaian pada mutu. Tegasya mutu adalah sifat-sifat jasa dan hasilnya yang sesuai dengan dan bahkan melebihi harapan, keinginan dan kebutuhan para pelanggan baik masa kiini maupun pada masa akan datang (Syafaruddin \& Asrul, 2018: 118).

Pelayanan pendidikan yang bermutu merupakan refleksi dari penerapan inilai-inilai kemanusiaan, inilai-inilai keagamaaan, inilai-inilai etika, inilai-inilai demokrasi dalam pelaksanaan pendidikan. Hal ini disebabkan pendidikan merupakan proses pemanusiawian manusia, dengan demikian hal ini berarti menghormati kebebasan peserta didik untuk menjadi dirinya sendiri (Syafaruddin, 2019: 181).

Pengelolaan pendidikan Islam merupakan salah satu penopang kehidupan yang urgent untuk membangun peradaban dan menjadi kan manusia yang lebih baik dan berkarakter serta penuh dengan "keridhaan" Tuhan. Pengelolaan pendidikan Islam yang profesional 
dan bermutu bukan merupakan hal yang mudah bagi seseorang atau lembaga pendidikan. Dibutuhkan komuinikasi yang bersifat nteraktif, reasional, dan transaksional, didalamnya melibatkan sumber komuinikasimengirimkan pesanpesan tertentu kepada penerima dengan maksud dan tujuan tertentu (Syafaruddin \& Erawadi: 2020: 222).

Perkembangan pendidikan di Indonesia yang saat ini masih lebih rendah dibandingkan dengan pendidikan di negara lain di Asia Tenggara. ndikator rendahnya mutu pendidikan dapat diamati pada prestasi-prestasi peserta didik. Dalam skala nternasional, menurut Laporan Bank Duinia tahun 2014, studi EA (International Association for the Evaluation of Education Achievement) di Asia Timur memperlihatkan bahwa keterampilan membaca peserta didik kelas V SD berada pada level terendah. Gambaran rata-rata skor tes membaca untuk peserta didik SD adalah sebagai berikut: 75,5 (Hongkong), 74,0 (Singapura), 65,1 (Thailand), 52,6 (Filipina), 51,7
(Indonesia). Anak-anak Indonesia ternyata hanya mampu menguasai $30 \%$ dari materi bacaan dan mereka kesulitan menjawab soal-soal berbentuk uraian yang memerlukan penalaran. Demikian juga dalam duinia pendidikan tinggi menurut majalah Asia Week dari 77 uiniversitas yang disurvei di Asia Pasifik ternyata empat uiniversitas terbaik Indonesia hanya mampu menempati peringkat ke-61, ke-68, ke-73, dan ke-75. ndikator lain yang menunjukkan betapa kurang bermutunya pendidikan di Indonesia adalah peringkat ndeks Pengembangan Manusia (Human Developmental ndex), yakini komposisi dari peringkat pencapaian pendidikan, kesehatan, dan penghasilan per kepala yang menunjukkan bahwa ndeks pengembangan manusia Indonesia makin menurun. Dari data UNESCO tahun 2010, di antara 174 negara di duinia, Indonesia menempati urutan ke 102 pada tahun 2006, ke-99 tahun 2007, ke-105 tahun 2008, dan ke-109 tahun 2009, serta menurun ke urutan 112 pada tahun 2014 (Tilaar, 2015: 13). 
Pengembangan budaya mutu pendidikan untuk melahirkan manusia-manusia unggul (insan kamil) dengan berpegang teguh kepada alquran dan sunnah (selain nalar juga wahyu) (Assegaf, 2011: 2) merupakan suatu bentuk kemutlakan pada ranah teoritis-normatif maupun aplikatif-normatif. Artinya, alquran dan sunnah merupakan inilai normatif yang "harus" dijadikan sebagai kerangka yang bermuara pada pandangan hidup, sikap hidup, dan tujuan hidup yang semuanya harus bernapaskan Islam dan dijiwai oleh ajaran-ajaran yang bersumber dari alquran dan sunnah yang salah satunya dilaksanakan di Perguruan Tinggi.

Perguruan Tinggi dituntut tanggung jawabnya atas jasa layanan yang dinyatakan dan dijanjikan kepada masyarakat. Tanggung jawab tu dinyatakan sebagai akuntabilitas perguruan tinggi atas peran dan fungsi yang dijalankan atas kinerja penyelenggaraannya atas pelayanan yang diberikannya. Bagaimana medayagunakan sumber daya dan dana yang ada dan seberapa tinggi kinerja yang dilakukan untuk mencapai tujuan yang telah menjadi komitmennya. Tuntutan akuntabilitas dan tanggung jawab mengharuskan perguruan tinggi memberi penjaminan mutu (quality assurance) kepada masyarakat (Ghafur, 2008: $5)$.

Pengembangan budaya mutu pendidikan melalui penyusunan rencana strategis merupakan salah satu bagian yang tidak terpisahkan dari strategi marketing. Budaya mutu akan datang dengan sendirinya dari upaya yang ditempuh sehingga komuinikasi dan keterbukaan dalam pelaksanaan rencana strategis merupakan salah satu faktor utama keberhasilan pengembangan budaya mutu. Sebagai upaya pencapaian visi, misi, dan tujuan lembaga pendidikan dalam mengembangkan budaya mutu pendidikan, artikel ini membahas tentang penyusunan rencana strategis dalam pengembangan budaya mutu pendidikan di Sekolah Tinggi Agama Islam Syekh H. Abdul Halim Hasan Al Ishlahiyah Binjai.

Dipilihnya Sekolah Tinggi Agama Islam Syekh H. Abdul Halim Hasan Al Ishlahiyah Binjai 
sebagai latar penelitian karena diinilai memiliki keuinikan tersendiri. Berdasarkan observasi pendahuluan yang dilakukan di Sekolah Tinggi Agama Islam Syekh H. Abdul Halim Hasan Al Ishlahiyah Binjai, didapat data yang menunjang penelitian tentang pelaksanaan rencana strategis dalam pengembangan budaya mutu pendidikan, pertama adanya dokumen rencana strategis, adanya Uinit Penjamin Mutu untuk melakukan tugas penyusunan rencana strategis, kualitas proses pembelajaran dan keluluasan untuk menjadi bahan masukan dalam proses penyusunan, pelaksanaan, dan evaluasi rencana strategis. Kedua, STAI Al Ishlahiyah Binjai dipercaya Kementrian Agama RI menyelanggarakan program bidik misi. Dari 37 PTKIS di lingkungan Kopertais wilayah X Sumatera Utara hanya dua Perguruan Tinggi yang ditetapkan, salah satunya Sekolah Tinggi Agama Islam Syekh $\mathrm{H}$. Abdul Halim Hasan Al Ishlahiyah Binjai. Program bidik misi merupakan program pemerintah untuk memberikan bantuan beasiswa kepada mahasiswa tidak mampu, tetapi berprestasi sampai tamat. Ketiga, penyusunan rencana strategis lebih dititik beratkan kepada pengembangan kapasitas (capacity building) yang meliputi pengembangan kelembagaan (institusi), pengembangan sumber daya manusia (SDM), pengembangan sarana dan prasarana, penggalian sumber dana dan pendanaan serta peiningkatan tata kelola (good governance).

\section{A. Metodologi Penelitian}

Metode penelitian ini menggunakan pendekatan kualitatif. Sumber data yang digunakan adalah sumber data primer dan sumber data sekunder. Strategi pengumpulan data dilakukan dengan cara wawancara, observasi, dan dokumentasi. Tekinik analisis data yang digunakan adalah model Miles dan Huberman yang meliputi tiga tahap yaitu reduksi data, penyajian data, dan penarikan kesimpulan. Tekinik penjaminan keabsahan data yang digunakan adalah uji kredibilitas, transferabilitas, dependabilitas dan konfirmabilitas terhadap 
penyusunan, pelaksanaan, dan evaluasi rencana strategis dalam pengembangan budaya mutu pendidikan di STAI Syekh H. Abdul Halim Hasan Al Ishlahiyah Binjai.

\section{B. Penyusunan Rencana Strategis} dalam Pengembangan Budaya Mutu Pendidikan di Sekolah Tinggi Agama Islam Syekh H. Abdul Halim Hasan Al IIshlahiyah Binjai

\section{Formulasi Visi, Misi, dan Tujuan}

Formulasi visi, misi, dan tujuan adalah usaha sistematis formal untuk menggariskan wujud utama dari perusahaan, sasaran-sasaran, kebijakan-kebijakan dan strategi untuk mencapai sasaran-sasaran dan wujud utama perusahaan yang bersangkutan.

Antara Visi, Misi, dan tujuan dalam rencana srategis memiliki hubungan yang sangat erat dan saling mebutuhkan.Visi adalah rumusan umum mengenai keadaan yang diinginkan padaakhir periode perencanaan. Misi adalah rumusan umum mengenai upaya-upaya yang akan dilaksanakan untuk mewujudkan Visi, sedangkan rencana strategis merupakan proses memutuskan program-program yang akan dilaksanakan oleh orgainisasi dan perkiraan jumlah sumber daya yang akan dialokasikan ke setiap program jangka panjang selama beberapa tahun ke depan (Hardjosoedarmo, 2004: 79).

Lebih jelasnya visi merupakan pernyataan tentang gambaran keadaan dan karakteristik yang ngin dicapai oleh suatu lembaga pada jauh dimasa yang akan datang. Misi merupakan pernyataan tentang apa yang harus dikerjakan oleh lembaga dalam usahanya mewujudkan visi dan hubungannya dengan rencana strategis adalah memberikan arah yang akan membawa lembaga dalam mencapai tujuan yang sesuai dengan visi dan misi yang telah dirumuskan. Berikut penjelasan ketiga komponen tersebut.

1) Visi

Visi adalah pernyataan tentang tujuan orgainisasi yang diekspresikan dalam produk dan pelayanan yang ditawarkan, kebutuhan yang dapat ditanggulangi, kelompok masyarakat yang dilayaini, 
inilai-inilai yang diperoleh serta aspirasi dan cita-cita masa depan. (Hardjosoedarmo, 2004: 80)

Visi merupakan cita-cita atau mpian sebuah orgainisasi atau perusahaan yang ngin dicapai di masa depan untuk menjamin kelestarian dan kesuksesan jangka panjang.

\section{2) Misi}

Sebuah misiorgainisasi adalah alasan keberadaan. Misi sering diungkapkan dalam pernyataan misi, yang menyampaikan rasa tujuan proyek kepada karyawan dan citra orgainisasi kepada pelanggan. Dalam perumusan proses strategi, pernyataan misi merupakan suasana hati perusahaan kemana harus pergi.

\section{3) Tujuan}

Tujuan adalah sasaran konkret orgainisasi berusaha untuk mencapainya, misalnya, sebuah target pertumbuhan pendapatan. Tujuan yang dirumuskan harus mampu mendorong manajer untuk segera melakukan aktivitas sekarang yang perlu dalam rangka mencapai target 5 tahun ke depan dan membantu manajer untuk meinimbang dampak dari tindakan sekarang pada kinerja perusahaan dalam jangka panjang.

\section{Analisis Tujuan dan Strate- gi Saat ini}

Tujuan adalah tujuan konkret orgainisasi berusaha untuk mencapainya, misalnya, sebuah target pertumbuhan pendapatan. Dalam perjalanan waktu, manajer suatu orgainisasi akan kehilangan "minat" terhadap misi yang pertama kali mereka perjuangkan. Manajer harus diingatkan kembali pada misi awalnya. (Hardjosoedarmo, 2004: 81)

Berikut adalah langkahlangkah analisis tujuan danstrategi, di antaranya:

1) Memberikan pengarahan baik untuk manajer maupun karyawan nonmanajerial. Dengan rencana, karyawan dapat mengetahui apa yang harus mereka capai, dengan siapa mereka harus bekerja sama, dan apa yang harus dil- 
akukan untuk mencapai tujuan orgainisasi. Tanpa rencana, departemen dan ndividual mungkin akan bekerja sendiri-sendiri secara serampangan, sehingga kerja orgainisasi kurang efesien.

2) Mengurangi ketidakpastian. Ketika seorang manajer membuat rencana, dipaksa untuk melihat jauh ke depan, meramalkan perubahan, memperkirakan efek dari perubahan tersebut, dan menyusun rencana untuk menghadapinya.

3) Memiinimalisir pemborosan. Dengan kerja yang terarah dan terencana, karyawan dapat bekerja lebih efesien dan mengurangi pemborosan. Selain tu, dengan rencana, seorang menejer juga dapat mengidentifikasi dan menghapus hal-hal yang dapat meinimbulkan nefesiensi dalam orgainisasi.

4) Menetapkan tujuan dan standar yang digunakan dalam fungsi selanjutnya, yaitu proses pengontrolan dan pen- gevalusasian. Proses pengevaluasian atau evaluating adalah proses membandingkan rencana dengan kenyataan yang ada. Tanpa adanya rencana, manajer tidak akan dapat meinilai kinerja Perusahaan. (Thompson, and Strickland, 1996: 6).

\section{Pengkajian Lingkungan}

Pengkajian lingkungan melibatkan analisis SWOT-peinilaian nternal terhadap kekuatan dan kelemahan perusahaan dan peinilaian eksternal terhadap peluang dan ancaman yang dihadapi. (Thompson, and Strickland, 1996: 9).

Perencanaan menyangkut jangkauan masa depan dari keputusan-keputusan yang dibuat sekarang, untuk mengenal sistematis peluang dan ancaman dimasa mendatang. Dengan pilihan langkahlangkah yang tepat akan lebih menguntungkan perusahaan. Meliputi jangka pendek dan sampai jangka panjang.

Segala kemudahan dan kemungkinan hambatan dalam usaha 
mencapai tujuan perlu sediini mungkin diidentifikasi, agar persiapan dapat dilakukan.Disatu pihak perusahaan dapat meraih kemudahan dan manfaat optimal dengan kesempatan yang tersedia.

\section{Analisis Sumberdaya}

Dilakukan bersamaan dengan analisis lingkungan, melalui analisis kekuatan dan kelemahan orgainisasi. Tidak ada jadwal tetap untuk menganalisis usulan nvestasi. Setelah tersedia SDM mereka langsung menganalisis.

Perencana mengumpulkan proyek yang disetujui selama satu tahun untuk dimasukkan ke dalam anggaran modal. (Thompson and Strickland, 1996: 10). Ada batas waktu dalam hal anggaran untuk tahun depan sebelum awal tahun anggaran. Jika suatu usulan tidak memenuhi batasan waktu tersebut maka waktu persetujuan formalnya dapat mengganggu sampai tahun berikutnya.

\section{Identifikasi Kesempatan} Strategi

Kesempatan strategi merupakan gap antara situasi apabila orgainisasi menggunakan tujuan dan strategi yang dirumuskan dalam proses penentuan tujuan dengan situasi apabila orgainisasi menggunakan strategi sekarang ini (tanpa perubahan). Kesempatan strategis muncul apabila orgainisasi menetapkan tujuan baru yang lebih sulit, atau apabila ada persaingan yang ketat dan mengakibatkan orgainisasi tidak berhasil mencapai tujuan yang telah ditetapkan sebelumnya. dentifikasi kesempatan strategis dapat dilakukan dengan cara:

1) Menyusun berbagai alternatif kebijaksanaan dan tindakantindakan yang mungkin dapat dipilih.

2) Meinilai dan membandingkan untung rugi setiap alternatif kegiatan kebijakan.

3) Memilih dan menetapkan suatu alternatif yang paling cocok dan baik diantara alter- 
natif-alternatif lain (Vancil, 1977: 14)

Kesempatan strategi adalah peluang yang berkaitan dengan keterkaitan antara orgainisasi yang dikaji dengan lingkungannya (internal maupun eksternal) dimana peluang tersebut banyak mempengaruhi orgainisasi tersebut. Semua isu strategis adalah penting, tapi tidak semua su penting adalah strategis.

Langkah konkret dalam penyusunan rencana strategis di antaranya adalah:

1) Menetapkan jeinis usaha orgainisasi.

2) Menterjemahkan visi dan misi ke dalam suatu tujuan strategis yang terukur.

3) Menyusun strategi yang tepat untuk mencapai tujuan dan target.

4) Melakukan berbagai keputusan taktis dengan efektif dan efisien atas strategi terpilih.

5) Melakukan pembagian tugas, penyesuaian ter- hadap arah, tujuan, strategi dan pelaksanaannya sesuai dengan situasi terbaru (Robert, 1960: 22)

Langkah-langkah penyusunan renstra di atas menjadi panduan Sekolah Tinggi Agama Islam Syekh H. Abdul Halim Hasan Al Ishlahiyah Binjai dalam menyusun renstranya. Adapun penyusunan renstra STAI, sebagai berikut:

Penyusunan rencana strategis dalam pengembangan budaya mutu pendidikan di Sekolah Tinggi Agama Islam Syekh H. Abdul Halim Hasan Al Ishlahiyah Binjai dengan: pertama, merumuskan visi, misi, dan tujuan; kedua, membentuk Tim Penyusun Rencana Strategis; ketiga, proses perumusan; dan keempat, pengesahan rencanaan strategis tersebut. Tim Penyusun Rencana Strategis terdiri dari Ketua STAI, Wakil Ketua, Kepala Uinit Penjamin Mutu, Ka. Prodi, dan dosen. Setiap pihak yang terlibat dalam menyusun program dan strategi sesuai dengan bidangnya masing- masing dan untuk sasaran mutu pendidikan mengelola fasilitas, mulai dari pengadaan, 
pemeliharaan dan perbaikan, hingga pengembangan yang dapat menciptakan lingkungan kampus yang bersih, rapi, ndah sehingga dapat menciptakan kondisi yang menyenangkan baik bagi dosen maupun mahasiswa untuk berada di kampus. Penyusunan programprogram strategis, yaitu pengembangan program studi, sarana dan prasarana,tata kelola dan manajemen, pengembangan sumber daya manusia (SDM), dana dan pendanaan, penjaminan mutu, penelitian, pengabdian pada masyarakat, dan kerjasama dengan mengembangkan budaya mutu, yaitu: komuinikasi yang terbuka dan kontiiniu, kemitraan nternal yang saling mendukung, kerjasama tim, kedisiplinan, dan tanggung jawab. Langkah berikutnya adalah mensosialisasikannya kepada stakeholder, civitas akademika, dan nstansi negeridan swasta agar kut mensukseskan rencana strategis yang telah disusun. Sebagai acuan utama dalam upaya mengungkapkan landasan akademisnya dari proses ini adalah delapan langkah proses rencana strategis menurut Richard F.
Vancil. ${ }^{1}$ Sedangkan analisis SWOT dimaksudkan untuk menemukan posisi strategis Sekolah Tinggi Agama Islam Syekh H. Abdul Halim Hasan Al Ishlahiyah Binjai. Selanjutnya, posisi strategis dimanfaatkan dalam penyusunan rencana strategis. Dapat disimpulkan bahwa Sekolah Tinggi Agama Islam Syekh H. Abdul Halim Hasan Al Ishlahiyah Binjai memiliki sedikit kekuatan tapi memiliki peluang yang besar untuk mengembangkan orgainisasi. Maka strategi yang harus diterapkan adalah mendukung kebijakan pertumbuhan yang agresif (Growth Oriented Strategy). Proses penyusunan rencana strategis Sekolah Tinggi Agama Islam Syekh H. Abdul Halim Hasan Al Ishlahiyah Binjai, secara akademis mengacu kepada tahapan-tahapan proses rencana strategis yang dikemukakan Richard F. Vancil, sehingga dapat dikatakan prosesnya berkualitas.

Dalam rapat penyusunan renstra tahun 2011 membahas

1 Richard F. Vancil, Strategy formulation in complex organizations. Strategic Planning Systems.Peter Lorange and Richard F. Vancil, eds. (Englewood Cliffs, N.J.: Prentice- Hall, Inc., 1977), h. 4 
tentang: keikutsertaan program studi dalam perencanaan pendanaan, gedung serta sarana dan prasarana lainnya milik sendiri, fasilitas Local Areal Network (LAN), pemanfaatan fasilitas laboratorium belum digunakan secara optimal bagi dosen dan mahasiswa untuk melaksanakan kegiatan penelitian, pendanaan program studi masih bersumber dari dana mahasiswa., dana di kelola terpusat oleh Sekolah Tinggi, sistem nformasi sudah bisa diakses oleh mahasiswa dari jarak jauh. Adanya Hibah Kompetisi Institusi dari Dikti untuk melengkapi peralatan yang dalam program hibah peralatan dan bantuan lainnya. Dampak pertumbuhan ekonomi nasional dan krisis ekonomi global. Pengelolaan Sistem nformasi Perguruan Tinggi Sejeinis yang dapat diakses dari jarak jauh.

Di STAI ditemukan running text yang dapat dilihat oleh seluruh tamu yang datang ke Sekolah Tinggi Agama Islam Syekh H. Abdul Halim Hasan Al-IIshlahiyah Binjai. Runining text tersebut menginformasikan tentang seluruh kegiatan kampus seperti jadwal masuk, KKN, Seminar Proposal sampai jadwal Sidang Skripsi yang mempermudah mahasiswa mengetahui nformasi terkiini di STAI Syekh H. Abdul Halim Hasan Al-IIshlahiyah Binjai

Kepala Uinit Penjamin Mutu Sekolah Tinggi Agama Islam Syekh H. Abdul Halim Hasan Al Ishlahiyah Binjai menyatakan bahwa ketersediaan rencana strategis menjadi acuan bagi Sekolah Tinggi Agama Islam Syekh H. Abdul Halim Hasan Al Ishlahiyah Binjai dalam melaksanakan proses perkuliahan agar perkuliahan selalu up tu date dan relevan dengan perkembangan dan tuntutan zaman. Dalam pelaksanaan pengembangan budaya mutu kampus diadakan peininjauan kurikulum miinimal 5 (lima) tahun sekali agar muatan kurikulum sesuai dengan tuntutan dan perkembangan lmu pengetahuan. Kurikulum yang disusun tidak hanya memuat satu kompetensi, tetapi harus memiliki beberapa kompetensi sehingga mahasiswa mendapatkan banyak pengetahuan baru dan sesuai dengan kebutuhan di duinia kerja. 
Uinit Penjamin Mutu bertugas merumuskan dan mengontrol ketepatan waktu penyelesaian studi mahasiswa. Proses perkuliahan dan lulusan yang berkualitas belum dianggap baik jika waktu penyelesaian studi melebihi waktu yang ditentukan. Masa studi S1 ditentukan selama 8 (delapan) semester 4 (empat) tahun. Hal ini menjadi perhatian khusus Uinit Penjamin mutu, karena tu dalam beberapa tahun ke depan, rata-rata penyelesaian studi mahasiswa adalah 4 (empat) tahun. Sekolah Tinggi Agama Islam Syekh $\mathrm{H}$. Abdul Halim Hasan Al Ishlahiyah Binjai pada tahun 2016 memiliki 2.410 orang mahasiswa yang terbagi ke dalam dua program studi, yaitu Prodi Pendidikan Agama Islam (PAI) dan Perbankan Syariah (PS). Dengan rincian mahasiswa prodi PAI 1.386 orang dan mahasiswa prodi PS berjumlah 1.024 orang. Setiap tahun jumlah mahasiswa terus bertambah seiring dengan perkembangan fisik serta sarana prasarana dan fasilitas Sekolah Tinggi Agama Islam Syekh H. Abdul Halim Hasan Al Ishlahiyah Binjai. Di samping tu, program studi
PAI, Prodi Perbankan Syariah dan nstitusi terakreditasi BAN-PT. Sekolah Tinggi Agama Islam Syekh H. Abdul Halim Hasan Al Ishlahiyah Binjai mendapatkan peringkat "B" dari BAN-PT Nomor: 174/SK/BANPT/Ak-XVI/S/VIII/2013 Tanggal 24 Agustus 2013.

$$
\begin{aligned}
& \text { Pada pelepasan wisuda } \\
& \text { terakhir tahun 2015, berhasil }
\end{aligned}
$$
menamatkan 185 orang, terdiri dari 144 orang dari jurusan Pendidikan Agama Islam (PAI) yang berhak menyandang Sarjana Pendidikan Islam (S.Pd.I) dan 41 orang dari jurusan studi Perbankan Syariah dengan gelar Sarjana Ekonomi Syari'ah (SE.I) Lulusan sarjana tahun 2015, 90 persen lulusan yang tepat waktu menyelesaikan studinya. Rata-rata 4 tahun 2 bulan dapat meraih sarjana“. Lebih menggembirakan inilai ndek Prestasi Kumulatif (IPK) rata-rata diatas 3,00.

$$
\begin{aligned}
& \text { Penelitian ini juga } \\
& \text { menemukan bahwa proses } \\
& \text { penyusunan rensta dimulai dengan } \\
& \text { menyusun program strategis. Adapun } \\
& \text { tekinis pengembangan budaya mutu } \\
& \text { pendidikan yang dilakukan oleh }
\end{aligned}
$$


Sekolah Tinggi Agama Islam Syekh

H. Abdul Halim Hasan Al Ishlahiyah

Binjai adalah dengan cara mengajak semua dosen melakukan rapat kerja khusus, dimulai dengan pemberian orientasi dan pengarahan dari Ketua Sekolah Tinggi Agama Islam Syekh H. Abdul Halim Hasan Al Ishlahiyah Binjai, dilanjutkan dengan orientasi dari nara sumber, kemudian diteruskan pada orientasi dan diskusi, semua dosen diberi waktu untuk membuat pengembangan budaya mutu yang dibinanya secara berkelompok sesuai dengan mata tupoksi yang dipegang agar diketahui tingkat pemahaman mereka, kemudian diadakan peinilaian kembali untuk presentasi dihadapan semua peserta. Setelah usai, semua dosen diminta menyempurnakan rencana strategis dan harus sudah jadi sebelum memasuki tahun pelajaran baru.

Walaupun masing-masing dosen memiliki pendapat yang sama tentang rencana strategis, namun dalam realisasinya berbeda. Hal tu tampak dari penerapan di dalam pelaksanaannya. Banyak faktor yang mempengaruhi fakta tersebut, bisa jadi karena waktu, kemampuan dosen, keadaan mahasiswa, media dan suasana dalam pelaksanaannya.

$$
\text { Penyusunan renstra juga }
$$

memperhatikan kekuatan dan kelemahan STAI Syekh H. Abdul Halim Hasan Al Ishlahiyah Binjai. Di antara kekuatan-kekuatan yang dimiliki STAI Syekh H. Abdul Halim Hasan Al Ishlahiyah Binjai adalah: pertama, memiliki gedung sendiri. Kedua, lokasi kampus yang sangat strategis. Ketiga, didukung oleh kepemimpinan yayasan yang kuat. Keempat, memiliki team work yang tangguh. Kelima, jumlah mahasiswa yang relatif banyak. Sedangkan di antara kelemahankelemahan yang dimiliki adalah: pertama, jumlah sarana dan prasarana yang belum memadai. Kedua, jumlah Program Studi yang masih miinim. Ketiga, pendanaan yang masih kurang. Keempat, tenaga edukatif yang dipersyaratkan belum mencukupi. Kelima, tata kelola yang belum maksimal. Keenam, belum adanya penjaminan mutu masingmasing Prodi. 
Peluang-peluang yang dapat dimanfaatkan oleh STAI dalam pengembangan budaya mutu yaitu: pertama, banyaknya jumlah SLTA di Kota Binjai dan Kabupaten disekitarnya yang merupakan nput calon mahasiswa. Kedua, banyaknya angkutan kota yang melintas di lokasi kampus yang memudahkan akses bagi mahasiswa. Ketiga, adanya perhatian dan dukungan Pemerintah Daerah dalam penyelenggaraan Perguruan Tinggi. Keempat, kepercayaan masyarakat yang relatif baik. Sedangkan tantangan yang dihadapi adalah: pertama, tingginya daya saing Perguruan Tinggi. Kedua, kecilnya ketersediaan lapangan kerja bagi lulusan Prodi yang ada.

Penyusunan rencana strategis dan pelaksanaannya baik mulai perencanaan, pengorgainisasian, pergerakan dan pengevaluasi, dengan mengedepankan koordinasi komuinikasi terbuka diantara civitas akademika. Keterbukaan semua pihak civitas akademika dalam de, gagasan, pendapat, nformasi, kepercayaan dan kekompakan memudahkan menyusunan rencana strategis.

Rencana strategis merupakan komponen penting dalam manajemen nstitusi karena menjadi panduan dan pedoman dalam memberikan pelayanan pendidikan kepada pelanggan dan stakeholder. Rencana strategis sangat penting bagi kampus sehingga harus dirancang sendiri oleh kampus dengan memperhitungkan kondisi nyata dan sumberdaya yang dimiliki untuk menjadi landasan dan pedoman kerja bagi setiap orang di kampus dalam menjalankan tugas dan fungsinya. Penyusunan rencana strategis yang dilakukan dalam Pengembangan Budaya Mutu Pendidikan Islam di Sekolah Tinggi Agama Islam Syekh H. Abdul Halim Hasan Al Ishlahiyah Binjai sesuai dengan ajaran Islam yang komprehensif berlandasakn Alquran dan as-Sunnah, dimana Islam mendidik ndividu menjadi manusia yang beriman, berakhlak yang mulia dan beradab yang kemudian melahirkan masyarakat yang bermartabat, teori ini didasarkan pada firman Allah QS. alTaubah: 9: 122: 


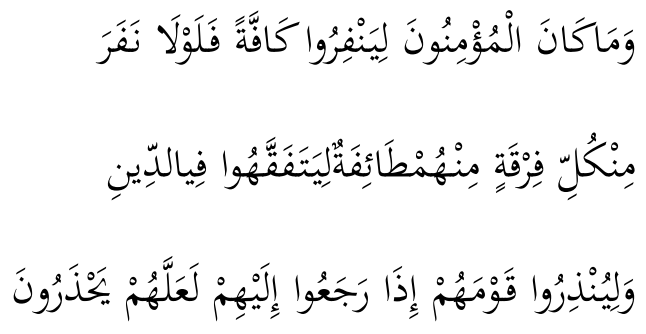

"Tidak sepatutnya bagi mukmiinin tu pergi semuanya (ke medan perang). Mengapa tidak pergi dari tiap-tiap golongan di antara mereka beberapa orang untuk memperdalam pengetahuan mereka tentang agama dan untuk memberi peringatan kepada kaumnya apabila mereka Telah kembali kepadanya, supaya mereka tu dapat menjaga dirinya". (Departemen, 2001: 986).

Ayat di atas menunjukkan bahwa tidaklah sepantasnya seluruh ndividu orang-orang yang beriman (muslim) berangkat kemedan perang untuk memerangi kaum Kuffar dengan menggunakan senjata, akan tetapi hendaknya terdapat salah seorang diantar setiap golongan mencari pendidikan yang layak agar kembali kepada masyarakatnya dan mendidik mereka agar senantiasa menjaga diri mereka dan keluarga mereka dari jilatan api Neraka.
Proses penyusunan dilakukan secara bermusyawarah dengan saling meminta dan mendengarkan pendapat berbagai pihak dalam membicarakan atau menyelesaikan suatu masalah sesuai dengan sabda nabi Muhammad saw.:

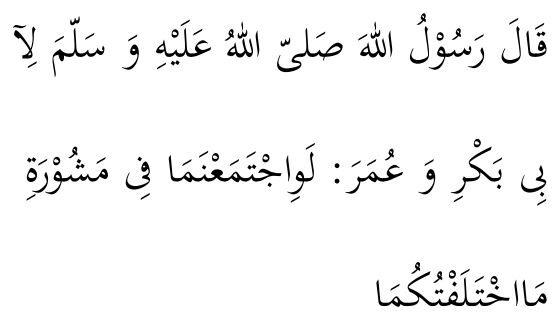

"Telah bersabda Rasulullah saw. Kepada Abu Bakar dan Umar: "Apabila kalian berdua sepakat dalam musyawarah, maka aku tidak akan menyalahi kamu berdua." (Ahmad, th: 82)

Bibit dari kebebasan berpikir ini sesungguhnya ditanam langsung oleh Rasul saw. Beliau telah mencontohkan sendiri bagaimana menjadi pribadi yang terbuka terhadap pendapat orang lain. Sikap ini dengan sendirinya berarti pemberian kebebasan bagi para sahabatnya untuk berpikir dan mengemukakan pandangannya. 


\begin{abstract}
Penyusunan rencana strategis yang dilakukan dalam Pengembangan Budaya Mutu Pendidikan Islam di Sekolah Tinggi Agama Islam Syekh H. Abdul Halim Hasan Al Ishlahiyah Binjai direncanakan melalui proses pembagian kerja. Pelaksanaan program bidang rencana strategis di Sekolah Tinggi Agama Islam Syekh H. Abdul Halim Hasan Al Ishlahiyah Binjai diatur dalam bentuk pembagian tugas melalui kepainitiaan. Dalam kepainitiaan pelaksanaan program bidang rencana strategis melibatkan dewan Dosen, wali mahasiswa dan masyarakat untuk saling membantu dan bekerja sama baik dalam proses pendidikan dan ouput pendidikan.
\end{abstract}

Jika penyusunan rencana strategis melibatkan semakin banyak pihak, maka rencana strategis yang disusun menjadi tanggung jawab banyak pihak pula untuk melaksanakannya dan pelaksanaannya akan semakin efektif dan efisian. Karena setiap pekerjaan yang dikerjakan bersama-sama membuat pekerjaan tersebut lebih mudah dan biasanya hasilnya juga lebih baik.

\section{Penyusunan rencana strategis} dalam pengembangan budaya mutu pendidikan Sekolah Tinggi Agama Islam Syekh H. Abdul Halim Hasan Al Ishlahiyah Binjai dapat dilihat pada diagram berikut: 
Diagram 1: Langkah-langkah Penyusunan

Rencana Strategis

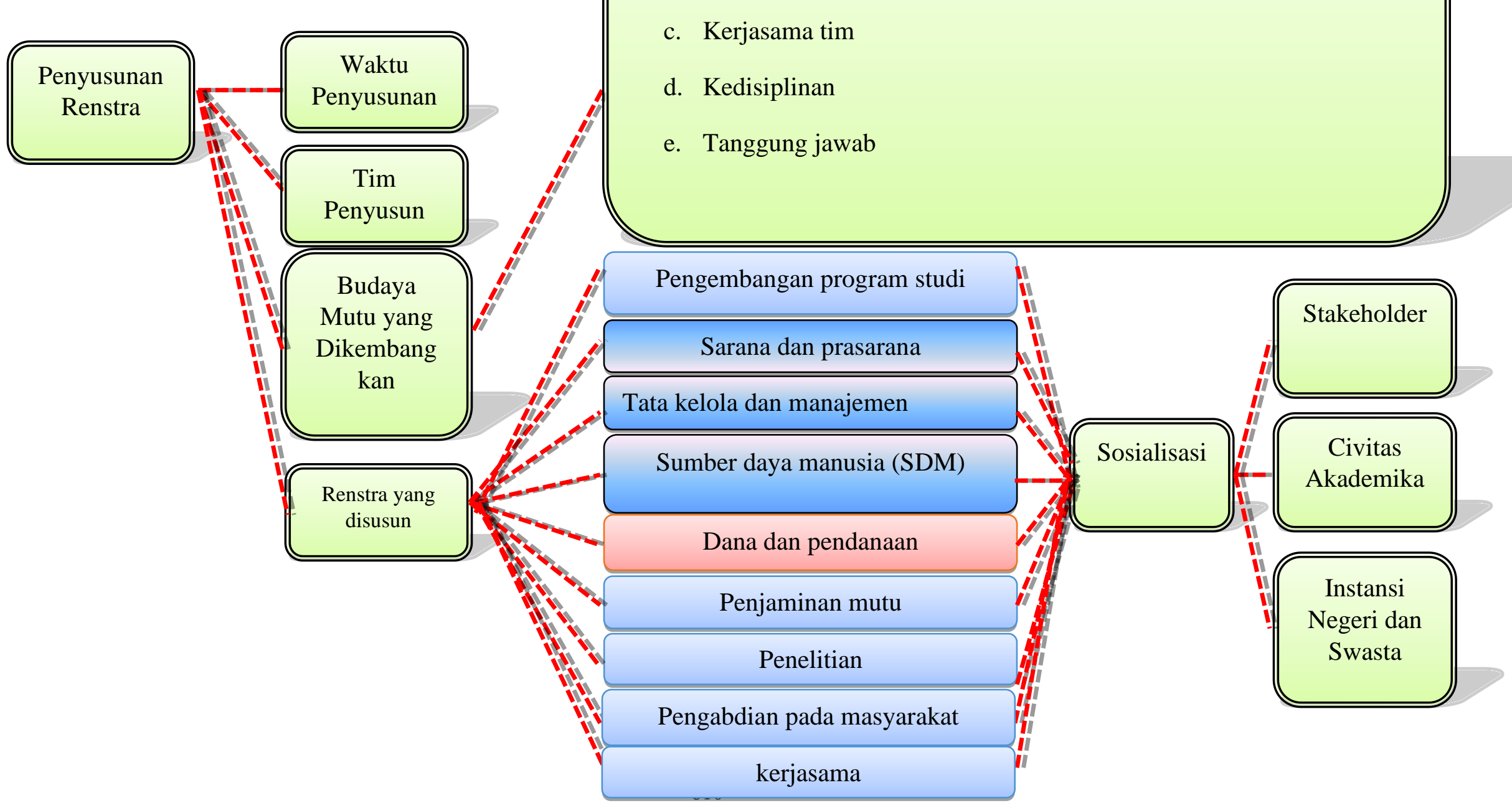

a. Komunikasi yang terbuka dan kontiniu

b. Kemitraan internal yang saling mendukung

c. Kerjasama tim

Kedisiplinan

Tanggung jawab 


\section{A. Penutup}

1. Simpulan

Penyusunan rencana strategis dalam pengembangan budaya mutu pendidikan di Sekolah Tinggi Agama Islam Syekh H. Abdul Halim Hasan Al Ishlahiyah Binjai dengan: pertama, merumuskan visi, misi, dan tujuan; kedua, membentuk Tim Penyusun Rencana Strategis; ketiga, proses perumusan; dan keempat, pengesahan rencanaan strategis tersebut. Tim Penyusun Rencana Strategis terdiri dari Ketua STAI, Wakil Ketua, Kepala Uinit Penjamin Mutu, Ka. Prodi, dan dosen. Setiap pihak yang terlibat dalam menyusun program dan strategi sesuai dengan bidangnya masing- masing dan untuk sasaran mutu pendidikan mengelola fasilitas, mulai dari pengadaan, pemeliharaan dan perbaikan, hingga pengembangan yang dapat menciptakan lingkungan kampus yang bersih, rapi, ndah sehingga dapat menciptakan kondisi yang menyenangkan baik bagi dosen maupun mahasiswa untuk berada di kampus. Penyusunan program-program strategis, yaitu pengembangan program studi, sarana dan prasarana,tata kelola dan manajemen, pengembangan sumber daya manusia (SDM), dana dan pendanaan, penjaminan mutu, penelitian, pengabdian pada masyarakat, dan kerjasama dengan mengembangkan budaya mutu, yaitu: komuinikasi yang terbuka dan kontiiniu, kemitraan nternal yang saling mendukung, kerjasama tim, kedisiplinan, dan tanggung jawab. Langkah berikutnya adalah mensosialisasikannya kepada stakeholder, civitas akademika, dan nstansi negeridan swasta agar kut mensukseskan rencana strategis yang telah disusun.

\section{Saran}

1. STAI, Dosen, dan Staf Syekh H. Abdul Halim Hasan Al Ishlahiyah Binjai

Diharapkan lebih aktif berkomunikasi dengan masyarakat agar penyusunan rencana strategis mempunyai dampak eksternal dan internal yang seimbang bagi lembaga. Serta melibatkan semua unsur Sekolah Tinggi yang terkait dalam kegiatan rencana strategis. Demi kelancaran komunikasi internal Sekolah Tinggi memberikan kontribusi terhadap kelancaran Rencana Strategis eksternal. Pengembangan staf mutlak dilakukan karena dosen dan karyawan merupakan sumber daya terpenting dalam kelancaran pelaksanaan proses belajar mengajar dan faktor penentu keberhasilan suatu program studi terutama dalam menghadapi tuntutan dan tantangan dalam persaingan di era global dan program ini akan canangkan dalam program pengembangan. Para dosen juga harus melihat relevansi kurikulum dengan tujuan prodi, rasio Jumlah kelas 
sebagai sarana pembelajaran dengan jumlah mahasiswa optimal, ruang Aula, dan sarana olah raga sebagai media berinteraksi antara dosen dan mahasiswa menumbuhkan suasana kebersamaan, tingkat kehadiran dosen dalam perkuliahan baik. Sistem pembelajaran juga hendaknya menggunakan media IT masih terbatas pada sarana LCD, Laptop/Komputer, belum tersedia iInternet dan fasilitas $e$ learning sebagai media melakukan upload materi kuliah bagi dosen dan yang dapat di down load oleh mahasiswa secara on-line. Sudah saatnya melakukan penyempurnaan sarana pembelajaran dan pengembangan sarana pembelajaran melalui hibah-hibah yang ada untuk meningkatkan kompetensi lulusan, menyediakan berbagai bahan ajar yang bisa diakses secara luas, melakukan inovasi perkembangan teknologi informasi yang sangat cepat di lembaga pendidikan, dan mengembangkan bahan ajar berbasis multimedia yang sangat cepat. Keteladanan positif spritualistik dari dosen dan juga semua guru muslim bahkan terutama dari pimpinan Sekolah Tinggi Agama Islam Syekh H. Abdul Halim Hasan Al Ishlahiyah Binjai, perlu digalakkan lagi, terutama dalam melaksanakan shalat sebagai cerminan keberagamaan yang tinggi dalam diri seorang pendidik. Karena faktor keteladanan ini menjadi sangat efektif dilakukan oleh seluruh elemen sekolah dalam rangka mencapai visi dan misi secara proporsional dan seimbang antara penguasaan ilmu pengetahuan berbasis teknologi informasi dan penyiapan generasi penerus yang memiliki iman, taqwa, dan berbudi pekerti luhur.

2. Lembaga Pendidikan Islam di IIndonesia

Sebagai masukan agar penyusunan rencana strategis di lembaga pendidikan Islam terus mengalami perkembangan dan peningkatan kualitas hingga optimal, kemudian bisa menjadi lembaga pendidikan Islam yang berkomitmen tinggi dalam memelihara hubungan yang harmonis dengan masyarakat yang memiliki keberagaman suku, ras, dan agama. Meningkatnya kebutuhan lembaga pendidikan terhadap tenaga kependidikan. Meningkatkan kesempatan untuk melakukan penelitian dan pengabdian kepada masyarakat.

3. Peneliti berikutnya

Disarankan untuk melakukan penelitian lebih lanjut dengan mengembangkan fokus lain sehingga hasilnya dapat mendukung teori manajemen rencana strategis dalam pengembangan budaya mutu pendidikan. Peneliti juga dianjurkan untuk mencari 
kasus lain yang memiliki karakteristik berbeda dengan kasus penelitian ini.

\section{DAFTAR PUSTAKA}

Ahmad bin Muhammad bin Hambal bin Hilal bin Asad Al Marwazi, Al Musnad, Beirut: Dar al-Ma'arif, t.th.

Anggoro, Linggar, Teori dan Profesi Kehumasan, Jakarta: Bumi Aksara, 2000.

Assegaf, Abd. Rachman, Filsafat Pendidikan s lam; Paradigma Baru Pendidikan Hadhari Berbasis ntegratif-Interkonektif, Jakarta: RajaGrafindo Persada, 2011.

Burhan, Manajemen Sumber Daya Manusia, Jakarta: Bumi Aksara,1994).

Departemen Agama RI, Al Qur'an dan Terjemahannya (Translitrasi ArabLatin) Model Perbaris, Semarang: Asy Syifa', 2001.

Donnelly, Total Quality Management as a Cultural Phenomenon, Jersey: Pearson Education nternational, 2004.

Coutney, Roger, Strategic Management forVoluntary Nonprofit Orgainizations, First published 2002.

Fidler, Brian, Strategic Managemen for School Development (London: Paul Chapman Publishing, 2002.

Ghafur, A. Hainif Saha, Manajemen Penjaminan Mutu Perguruan Tinggi di Indonesia, Jakarta: Bumi Aksara, 2008.

Hardjosoedarmo, S., Total Quality Management Yogyakarta: Andi, 2004.
Hitt, Michael A., Duane reland, and Robert E. Hoskisson, Strategic Management: Competitiveness and Globalization: Concepts, Ininth Edition, USA: South-Western a Part of Cengage Learining, 2011.

Kerzner, Harold, Strategic Management, New York: McGraw-Hill, 2001.

Morell, Robert W., Managerial DecisionMaking, Milwaukee, WI.: Bruce Publishing, 1960.

Robbins, Stephen P., Orgainizational Behavior, New Jersey: Pearson Education International, 2001.

Ruslan, Rosady, Manajemen Public Relations \& Media Komuinikasi, Bandung: Alfabeta, 2000.

Syafaruddin, Manajemen Orgainisasi Pendidikan: Perspektif Sains dan Islam, Medan: Perdana Publishing, 2017.

Syafaruddin \& Asrul, Kepemimoinan Pendidikan Kontemporer, Bandung: Citapustaka Media, 2018.

Syafaruddin, Manajemen \& Strategi Pembelajaran, Medan: Perdana Publishing, 2019.

Syafaruddin \& Erawadi, Manajemen dan Kepemimpinan Pendidikan Islam: Praktik Terbaik Manajemen dan Kepemimpinan di Lembaga Pendidikan Islam Zaman Baru, Medan: Perdana Publishing, 2020.

Sule, Tisnawati, Erinie, Saefullah, Kuriniawan,iPengantar Manajemen Edisi Pertama, Jakarta: Kencana, 2005.

Salusu, Panduan Manajemen Pendidikan Ala Harvard Uiniversity, Yogyakarta: Diva Press, 2004.

Tilaar, H.A.R., Standarisasi Pendidikan Nasional, Jakarta: Rineka Cipta, 2015 . 
Thompson, Arthur A., Jr. and A. J. Strickland II, Strategic Management: Concepts \& CasesBoston MA, Irwin/McGrawHill, 1996.

Vancil, Richard F., Strategy formulation in complex orgainizations. Strategic Planining Systems.Peter Lorange and Richard F. Vancil, eds. Englewood Cliffs, N.J. : PrenticeHall, Inc., 1977. 